\title{
CARING NURSES FROM THE PERSPECTIVE OF OTHER HEALTH PROFESSIONALS AT PROF. DR. WZ JOHANNES GENERAL HOSPITAL, KUPANG, EAST NUSA TENGGARA
}

\author{
Aemilianus Mau \\ Study Program of Nursing, School of Health Polytechnics, Ministry of Health, Kupang
}

\begin{abstract}
Background: Many studies on caring nurses based on patient perception has been done. However, to the extent of the author's knowledge, studies on caring nurses in the perspectives of other health professionals have never been done in Indonesia. This study aimed to analyze the caring nurses from the perspective of other health professionals at Prof. DR. WZ Johannes General Hospital, Kupang, East Nusa Tenggara.

Subjects and Method: A qualitative study with a phenomenological approach was conducted at Prof. Dr. W. Z. Johannes Hospital, Kupang, East Nusa Tenggara, from 25 April-25 May 2019. Six informants were selected in this study, including physician representatives, analysts, nutritionists, and pharmacists. Informants' criteria were education $\geq$ Diploma III, civil servant, length of work $\geq 3$ years, and willing to be an informant. The theme in this study was caring practice of nurses. The data were collected by in-depth interview and analyzed descriptively.

Results: Four themes of caring nurses: (1) Nurses who had concern and competence to deal with patient problem; (2) Nurses who worked professionally with empathy and respect to patients; (3) Nurses who served with heart and focus on service; (4) Nurses who were communicative, friendly, and trustworthy. The implementation of these four themes in nursing services was still lacking.

Conclusion: Caring nurses according to the other health professions have been defined as nurses who work professionally with concern, heart, an empathy to the patients, competence, respect, friendliness, trustworthiness, sound communication, and focused attention to care. A nursing training is needed to improve the implementation of caring practice.
\end{abstract}

Keywords: caring, practice, nurse

\section{Correspondence:}

Aemilianus Mau. Study Program of Nursing, School of Health Polytechnics, Ministry of Health, Kupang. Jl. Piet A. Tallo Liliba Kupang, East Nusa Tenggara. Email: aemilianusmau58@gmail.com. Mobile: 085235721092. 